\title{
SERIES
}

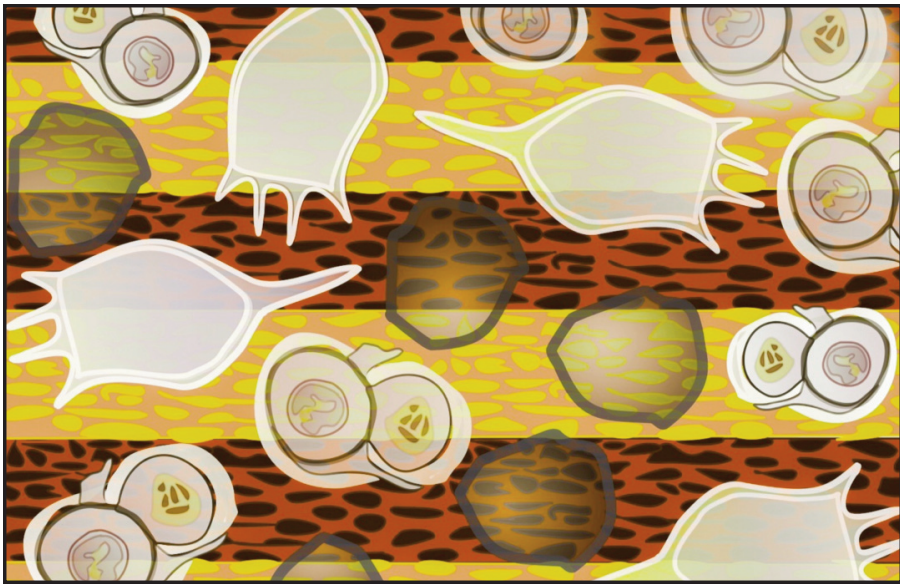

\section{Great Canadian Lagerstätten 5. Crawford Lake - A Canadian Holocene Lacustrine Konservat-Lagerstätte with Two- Century-Old Viable Dinoflagellate Cysts}

\author{
Department of Earth Sciences \\ Brock University \\ St. Catharines, Ontario, L2S 3 A1, Canada \\ E-mail: akrueger@brocku.ca
}

Andrea M. Krueger and Francine M.G. McCarthy

\section{SUMMARY}

In addition to commonly preserved microfossils like pollen and diatoms, the varved sediments of Crawford Lake, Ontario, contain the fossilized remains of otherwise rare microfossils. Bottom water anoxia resulted from the physiography of this small, deep lake and enhanced biochemical oxygen demand (BOD) during two distinct phases of human settlement: prehistoric Iroquoians (approximately 1268-1486 CE) and historic Euro-Canadians (since $1822 \mathrm{CE}$ ). The exceptional preservation of delicate organic-walled microfossils like rotifer loricae and cellulosic dinoflagellate thecae provides unparalleled insights into a Holocene freshwater lake ecosystem and allows the biological and taphonomic components of the fossil assemblage to be isolated. Bottom water anoxia may also have increased the longevity of cell contents: resting cysts of Parvodinium [Peridinium] inconspicuum (Lemmermann) Carty and
Peridinium volzii Lemmermann. These were germinated from varves deposited nearly two centuries ago, extending the known span of viability of dinoflagellates.

\section{RÉSUMÉ}

En plus des microfossiles couramment conservés comme le pollen et les diatomées, les sédiments varvés du lac Crawford en Ontario, contiennent les restes fossilisés de microfossiles très rares. Le caractère anoxique des eaux de fond s'explique par la physiographie de ce petit lac profond et par une augmentation de la demande biochimique en oxygène (DBO) durant deux phases distinctes de peuplement humain : phase préhistorique iroquoienne (environ 1268 à $1486 \mathrm{CE}$ ) et une phase historique euro-canadienne (depuis $1822 \mathrm{CE}$ ). La préservation exceptionnelle de délicats microfossiles à membranes organiques comme rotifère lorica et les thèques cellulosiques de dinoflagellés, ouvre une fenêtre inédite sur l'écosystème d'un lac d'eau douce Holocène et permet aux composants biologiques et taphonomiques de l'assemblage de fossiles d'être préservés isolément. L'anoxie des eaux de fond peut également avoir augmenté la longévité du contenu des cellules: kystes dormants de Parvodinium [Peridinium] inconspicuum (Lemmermann) Carty et de Peridinium volzii Lemmermann. Ces derniers ont été activés à partir de varves déposés il y a près de deux siècles, ce qui allonge la durée connue de la viabilité des dinoflagellés.

Traduit par le Traducteur

\section{INTRODUCTION}

The concept of Konservat-Lagerstätten is virtually absent from the Holocene literature (Allison and Briggs 1993), despite the fact that exceptionally preserved deposits would serve as an important quantifiable bridge between biological and paleontological records. Several examples of exceptionally preserved large mammals, like mammoths and bison, have been reported from permafrost, prehistoric human remains have been found in glaciers (e.g. Ötzi from the Eastern Alps and Kwäday Dän Ts'inch from the British Columbia Rockies) and peat bogs (Moorleiche like Tollund Man and Lindow Man; Painter 1991 and Oeggl et al. 2007), and concentrations of desiccated remains of plants and animals (Konzentrat-Lagerstätten) are known from cave deposits of various ages, including the Holocene. Examples of Lagerstätten representing a large fraction of the biocoenosis in modern lakes are rare, however, despite their relative abundance and the critical importance of freshwater resources. 
Lakes tend to be characterized by continuous and relatively rapid sedimentation conducive to excellent paleontologic resolution (Schindel 1980) and lacustrine Lagerstätten such as the Eocene Green River Shale (Bradley 1931; Grande 1980; Buchheim and Surdham 1981), the Oligocene Enspel 'oilshale' (Köhler and Clausing 2000; Poschmann et al. 2010), and the Miocene Clarkia Beds (Smiley and Rember 1981, 1985; Batten et al. 1999) provide exceptional insights into ancient continental environments. Long-term (pre-instrumental) environmental trends can be assessed through paleolimnology, but it is difficult to apply the abundant phycological and zoological literature to micropaleontological samples without understanding the impact of taphonomy on modern lake sediment. The optimal use of paleolimnological data to inform ecological management (e.g. Cabecinha et al. 2009; Smol 2010) depends on an accurate assessment of the biological community (biocoenosis), relative to the fossil assemblages (thanatocoenosis), requiring a thorough understanding of the impact of transport into and out of the lake, differential preservation of the various components of the ecosystem, and time-averaging of the record (Kidwell and Flessa 1996).

Meromictic lakes (lakes with layers of water that do not intermix, resulting in bottom water anoxia) have long been known to promote excellent preservation, allowing the biological component of variance between samples to be isolated from the taphonomic component (Bell et al. 1987). Additionally, the virtual absence of bioturbation allows for very high resolution in commonly annually laminated sediment (varves), although these are typically not very long records, since lakes tend to fill in (Schindel 1980). Annual chronological resolution in the late Holocene varved record of Crawford Lake, Ontario, allowed comparison with archaeological and historical records that document two distinct phases of human settlement and associated cultural eutrophication (Boyko 1973; Byrne and McAndrews 1975; McAndrews and Boyko-Diakonow 1989; Ekdahl et al. 2004, 2007; McAndrews and Turton 2010). As a result, in addition to commonly-preserved microfossils like pollen (Boyko 1973; Byrne and McAndrews 1975; McAndrews and Boyko-Diakonow 1989) and diatoms (Ekdahl et al. 2004, 2007) the varves deposited below the chemocline in the deep basin of Crawford Lake since the $13^{\text {th }}$ century CE contain the fossilized remains of otherwise rare microfossils. These provide exceptional insights into the lake ecosystem, compared with the vast majority of lacustrine records that have been more taphonomically altered.

\section{GEOLOGIC SETTING}

Crawford Lake occupies a small, deep dolostone basin adjacent to the edge of the Niagara Escarpment World Biosphere Reserve near Toronto (Fig. 1). The Crawford Lake Conservation Area has been designated as an Area of Natural and Scientific Interest (ANSI) by the Government of Ontario (Niagara Escarpment Plan 2005) due to its geological, ecological, and archaeological attractions - the latter including the 'Iroquoian Village' reconstructed in 1972 by the Halton Region Conservation Authority (Conservation Halton) following an archaeological survey (Finlayson 1998). This survey was initiated by the discovery of the remains of cultivars such as corn (Zea), and sunflower (Helianthus) pollen spores in varved sediment from around the middle of the last millennium (Fig. 2)
(Boyko 1973; Finlayson et al. 1973; Byrne and McAndrews 1975; McAndrews and Boyko-Diakonow 1989). This site, approximately $150 \mathrm{~m}$ from the lake, was intermittently occupied by between 200 and 300 people in the $13^{\text {th }}$ to $16^{\text {th }}$ centuries (Finlayson 1998; Byrne and Finlayson 1998) and was subsequently unoccupied until the Crawford homestead was established in ca. $1822 \mathrm{CE}$ (McAndrews and Boyko-Diakonow 1989). The peak abundance of ragweed (Ambrosia) and other non-arboreal pollen in the late $19^{\text {th }}$ century (Fig. 2) marks the most intensive Euro-Canadian impact in the watershed, when a sawmill operated on the southern shore of the small lake (Crawford Lake Conservation Area 2011).

The Crawford Lake basin is thought to have been excavated in relatively soft and soluble dolomite of the underlying Silurian Lockport Formation during the late Wisconsinan, when glacial meltwater flowed southward between two ablating ice lobes (McAndrews and Boyko-Diakonow 1989). Underground caves in this karstic region could have further facilitated this process. The lake does not fully overturn due to its relatively small surface area (about $250 \times 150 \mathrm{~m}$ ) and great depth (up to $22.5 \mathrm{~m}$ of water overlies approximately $4.5 \mathrm{~m}$ of postglacial sediment in the deepest part of the basin). Crawford Lake has a high affinity for meromixis (i.e. $Z r>2$ using the equation of Hutchinson (1957),

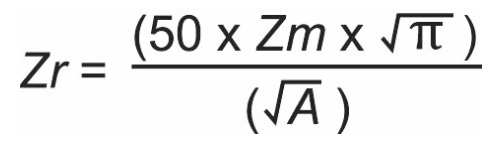

with $Z r=10.25$ (where $Z r=$ relative depth, $Z m=$ maximum depth, $A=$ surface area). Seepage from a catchment of about $80 \mathrm{~km}^{2}$ is the main inflow into this small (about $2.4 \mathrm{ha}$ ) lake, minimizing disturbance of the water column, and the mature eastern white cedar (Thuja occidentalis) forest on the slopes surrounding the lake acts as a wind-break, further reducing mixing of the water column (Yu et al. 1997). Water below the thermocline at around $15 \mathrm{~m}$ thus has a constant temperature of $5-6^{\circ} \mathrm{C}$ (McAndrews and Turton 2010) and over the last millennium bioturbation has been largely suppressed by bottom water anoxia. Since the $13^{\text {th }}$ century $\mathrm{CE}$, when the Iroquoian village was established and BOD (biochemical oxygen demand) increased due to cultural eutrophication (Ekdahl et al. 2004, 2007; Turton and McAndrews 2006), annual sediment couplets - varves - consisting of a white calcite-rich layer and a dark organic-rich layer (Figs. 3, 4) have accumulated because the anoxic bottom waters were unable to support benthic animals and protists (Dickman 1979). It has been proposed that episodic reduction in benthic anoxia at times of reduced productivity and BOD between the two phases of human settlement in the catchment (Chan, C., personal communication 2011, unpublished benthic ostracode data) may have interrupted varve formation, explaining the observation that about $10 \%$ of the varves are missing in the Post-Iroquoian Zone when compared to Accelerated Mass Spectrometry-C ${ }^{14}$ dating (Ekdahl et al. 2004, 2007). Nonetheless, varve counting together with carbon dating provides a very precise chronology, allowing the microfossil record to be compared with historic and archaeological data (Fig. 4). Freeze cores allow varves to be recovered, as the sediment freeze onto the hollow aluminum wedge filled with an ethanol and dry ice slurry; the wedge 

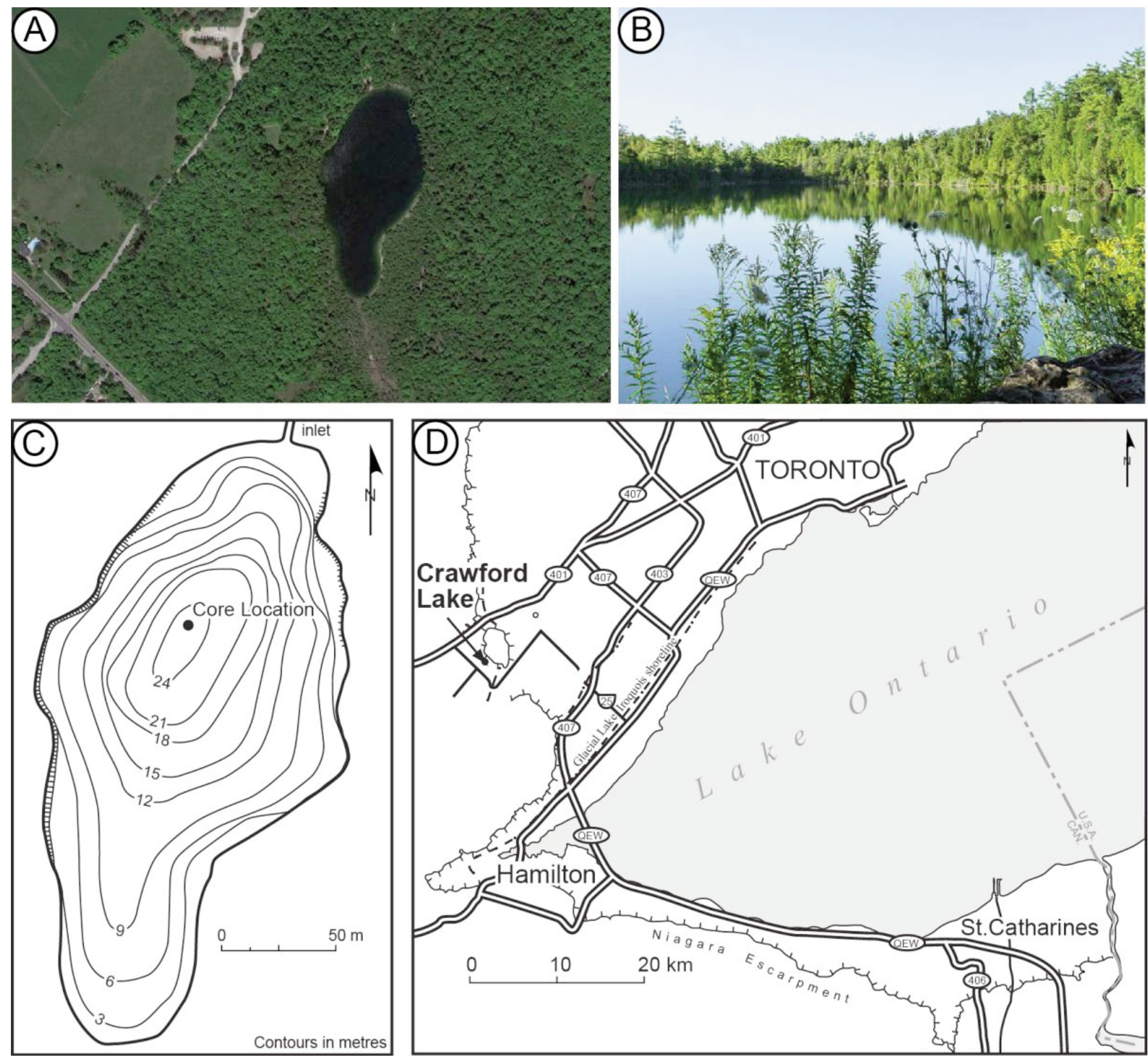

Figure 1. Aerial view (A) and shore view (B) photos of Crawford Lake, Milton, Ontario (Google images 2015). Bathymetry of the small, deep, meromictic Crawford Lake (C) near the edge of the Niagara Escarpment World Biosphere Reserve, about $50 \mathrm{~km}$ west of Toronto (D).

shape of the 'frigid finger' sampler allows for easy penetration into the sediments.

\section{EXCEPTIONALLY PRESERVED DINOFLAGELLATES}

In addition to commonly preserved pollen (Boyko 1973; Byrne and McAndrews 1975; McAndrews and Boyko-Diakonow 1989; Byrne and Finlayson 1998), fungal spores like corn smut (Ustilago maydis; McAndrews and Turton 2010), and diatoms (Ekdahl et al. 2004, 2007), rarely preserved microfossils are also found in varves deposited in the deep basin of Crawford Lake over the last 800 years. Turton and McAndrews (2006), for instance, reported common rotifer loricae that show a clear response to the increase in nutrients and abundance of algae during the Iroquoian and Euro-Canadian zone (Fig. 2). Fossil remains of these pseudocoelomate microscopic aquatic 'wheel animals' of the Phylum Rotifera are rare except for their resting eggs (van Geel 2001), but other body parts can accumulate under exceptional circumstances that inhibit oxygen, such as preservation in amber (Waggoner and Poinar 1993), in rapidly accumulating early Holocene sediment (Swadling et al. 2001), and a rare example of a complete rotifer in Permian sediment from India (Jha et al. 2011).

Rarely preserved cellulosic thecae of the dinoflagellate Parvodinium Peridinium] inconspicuum (Lemmermann) Carty (Fig. $5 \mathrm{~A}-\mathrm{C})$ were found together with abundant resting cysts in palynological preparations from varves deposited during the 


\section{Crawford Lake}

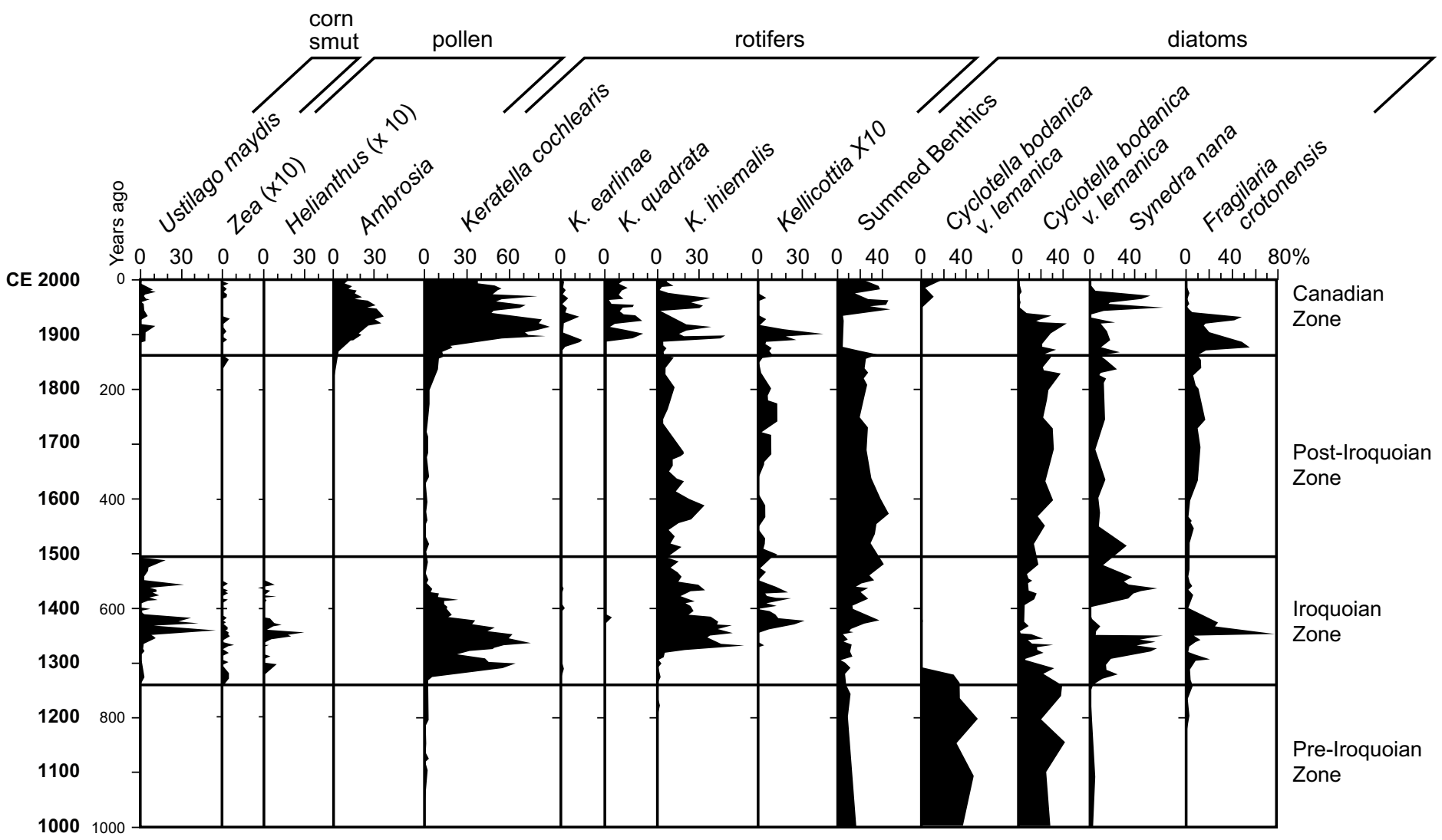

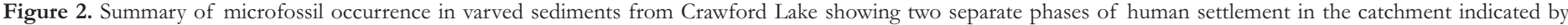

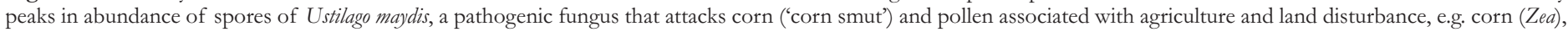

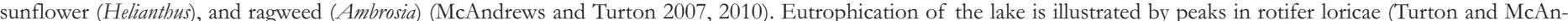

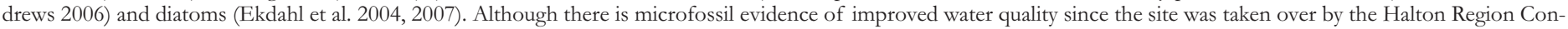
servation Authority (Conservation Halton) in 1972, the lake has not returned to pre-disturbance conditions.

early Iroquoian period $\left(13^{\text {th }}\right.$ century CE) and from the EuroCanadian Period (Fig. 6). Dinoflagellates are common components of the phytoplankton in lakes, with approximately 350 species of the Phylum Dinoflagellata Bütschli inhabiting freshwater environments (Popovsky and Pfiester 1990; Mertens et al. 2012; Carty 2014). They have large, unusual dinokaryotic nuclei in which the chromosomes have unmasked DNA fibrils and are more or less continuously condensed (Fensome et al. 1993). The large nuclei contain the red pigment responsible for 'red tides;' they are bright red just prior to mitosis (McCarthy et al. 2011) and thus impart a red colour to the water during algal blooms. The life history of most dinoflagellates consists of a motile (vegetative) stage in which armored thecae composed of several cellulosic plates whirl through the water column using their two flagellae - one transverse, along the cingulum (belt), and one longitudinal along the sulcus (groove) and at least one nonflagellated benthic stage (cyst) (Bravo and Figueroa 2014). Fossilizable (long-term) resting cysts are composed of dinosporin, a complex biomacromolecular substance composed of phenolic, alcoholic and/or carboxylic hydroxides, fatty acids with tocopherols, and sterols (Kokinos et al. 1998; Versteegh et al. 2012). These are produced by some, but not all, species, and to date are known for only about $20 \%$ of fresh water species (Mertens et al. 2012), a percentage comparable to marine taxa (Head 1996).
Unlike marine taxa, however, cyst-theca relationships are known for very few freshwater dinoflagellate taxa (Wall and Dale 1968; McCarthy et al. 2011; Mertens et al. 2012; Drljepan et al. 2014). Even in studies where both phycological and palynological approaches are combined (e.g. Chu et al. 2008), it has proven difficult to definitively relate thecae in the water column with dinoflagellate cysts preserved in sediment on the lakebed (Popovský 1983; McCarthy and Krueger 2013). As a result, few detailed paleolimnological studies have been published using dinocysts since Traverse (1955) recorded the first known fossil freshwater dinoflagellates (Peridinium hansonianum) from Oligocene lignite. Most of these are monospecific or very low diversity assemblages from sites exhibiting exceptional preservation, such as varved lacustrine deposits of the Miocene Clarkia lake succession in northern Idaho (Batten et al. 1999), the Upper Oligocene Enspel Lagerstätte in the Westerwald area of Germany (Köhler and Clausing 2000), rapidly deposited Holocene sediment from the alpine Lake Nero di Cornisello, Italy (Tardio et al. 2006), and Holocene microlaminated sediments from Lake Xiaolongwan in northeastern China (Chu et al. 2008). Drljepan et al. (2014) reported a relatively high diversity Holocene record from the deep basin of a meromictic lake in Massachusetts, particularly at times of natural and cultural eutrophication during the dry mid-Holocene 'hemlock minimum' when low lake levels are recorded 
Early Fall - prior to destratification of mixolimnion

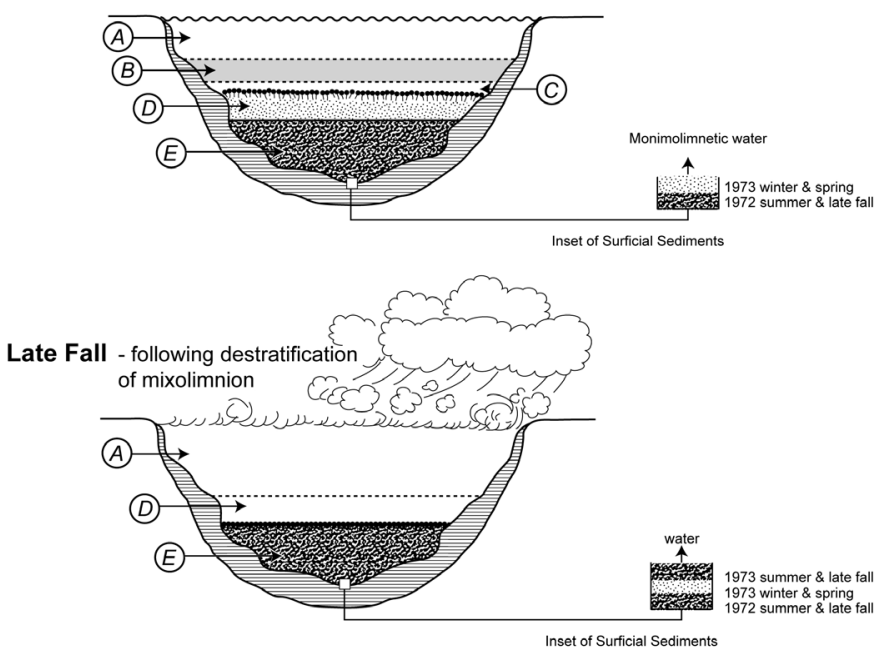

Early Spring - following restratification of mixolimnion

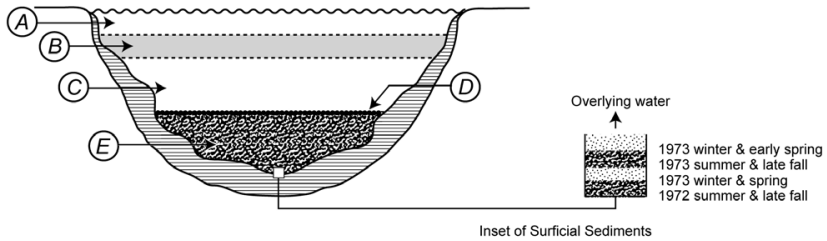

Figure 3. Mechanism of varve formation in Crawford Lake (modified from Dickman 1979). Wind mixing of the mixolimnion, surface waters, during fall turnover introduces oxygen into the chemocline and resulting mass mortality of photosynthetic anaerobic bacteria produces a dark organic-rich lamina; when water temperatures rise in spring, calcite starts to precipitate, forming a white calcium-rich lamina. (A) Upper mixolimnion; (B) thermocline; (C) lower mixolimnion (partially aerated zone); (D) lower mixolimnion (anaerobic zone); (E) monimolimnion. Sediment oxygen demand (SOD) produces bottom water anoxia, inhibiting bioturbation and promoting preservation of rare microfossils such as cellulosic thecae of dinoflagellates.

throughout New England, and over the last four centuries in response to anthropogenic impact.

Cellulosic dinoflagellate thecae are typically reported to be non-fossilizable, but rare examples of preservation have been reported from amber collected from a Late Albian/lowermost Cenomanian black paralic deposit in southwestern France (Masure et al. 2013) and from anoxic Recent sediment from another meromictic eastern North American lake (Drljepan 2014; Drljepan et al. 2014). The exceptional preservation of thecae of Parvodinium inconspicuum in several samples from Crawford Lake allowed Krueger (2012) to infer the affinity of the abundant tiny (about 16-20 $\mu \mathrm{m}$ in diameter), spherical, unornamented cysts with visible cell contents (illustrated in Fig. 5E with a rotifer lorica) in the same palynological preparations from varved sediments from a freeze core collected in February, 2011. The affinity of these tiny, spherical, unornamented cysts to Parvodinium inconspicuum was also confirmed by comparison with illustrations of the characteristic 'peanutshaped' cell during reproduction in Pfiester et al. (1984), when five samples dating from about 1920 to $1845-1860$ CE $(20 \mathrm{~cm}$ to $29 \mathrm{~cm}$ ) germinated during an unplanned hiatus in palynological processing (McCarthy and Krueger 2013). A $72 \mathrm{~cm}$ long freeze core was recovered on January 25, 2011, from the

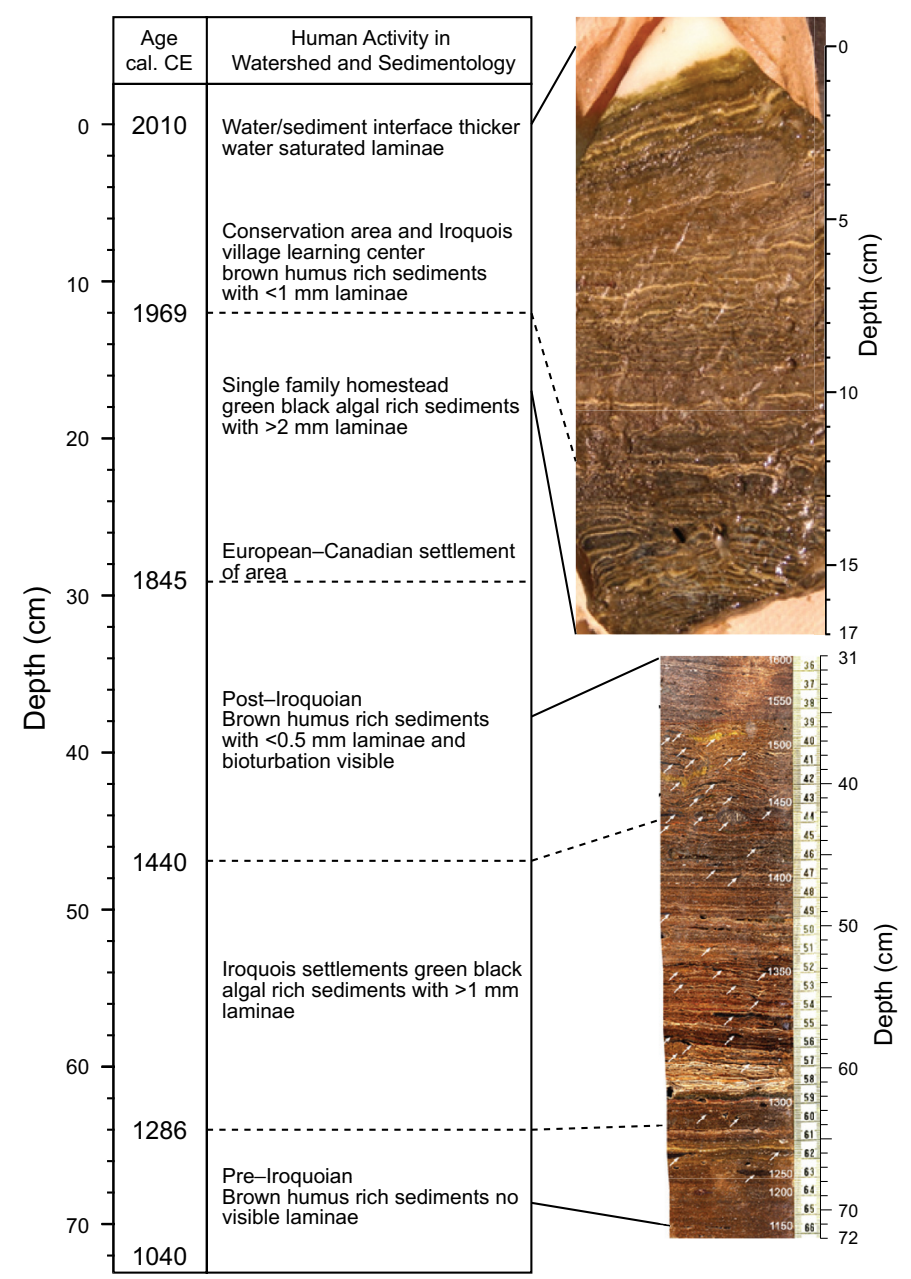

Figure 4. Varve counting provides a very precise chronology, allowing the microfossil record to be compared with historic and archaeological data. Both phases of human settlement, by the Iroquois (between 1268-1486 CE) and historic EuroCanadians (since around $1820 \mathrm{CE}$ ), are associated with a change in colour and increase in the thickness and continuity of laminae (from Krueger 2012).

deepest point in Crawford Lake (up to $22.5 \mathrm{~m}$ ) using a frigid fingernail sampler. The core was brought back to Brock University where it was kept in a freezer wrapped in dry ice awaiting further processing that occurred in late February 2011. Inadvertent culturing occurred when samples were left in test tubes for a week after processing with a weak $\mathrm{HCl}$ solution and rinsed with distilled water. The samples were kept at room temperature (about $22^{\circ} \mathrm{C}$ ) under fluorescent lights. This allowed the various stages of the dinoflagellate life cycle to be observed in the resulting slides (Fig. 7), including meiosis and mitosis showing the characteristic lack of breakdown of the nuclear envelope during mitosis (Fig. 5D). Excystment allowed us to suggest that the cysts inferred by Chu et al. (2008) to be cysts of Parvodinium inconspicuum are actually cysts of Parvodinium [Peridinium] umbonatum (Stein) Carty (McCarthy and Krueger 2013), probably because the thecae in the water column were incorrectly identified. Both the thecae and cysts of P. umbonatum were identified in sediment from a meromictic lake in Massachusetts (Drljepan et al. 2014) and the cysts resemble those illustrated by Tardio et al. (2006). The abundance of cysts of P. inconspicuum in Crawford Lake at times of anthropogenic impact is consistent with the tolerance of this 

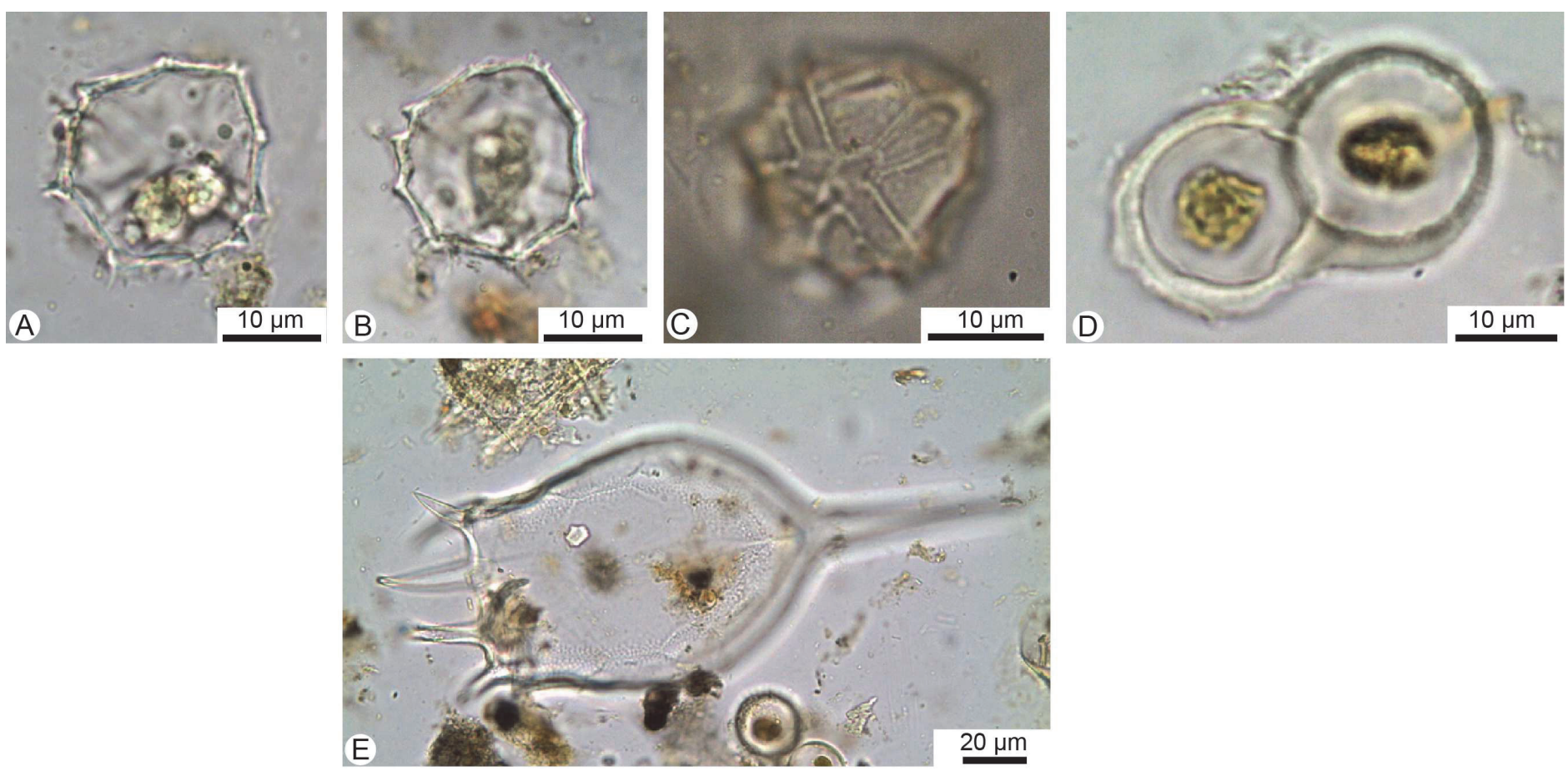

Figure 5. Small, thick-walled cellulosic thecae of Parvodinium [Peridinium] inconspicuum (Lemmermann) Carty with visible nucleus (A, B) and plate tabulation (C), and a hypnozygote of this taxon undergoing meiosis (D) (from Krueger 2012). A rotifer lorica (genus Keratella) with tiny cysts assigned to Parvodinium inconspicuum (E); note the large dinokaryotic nuclei.

\section{Crawford Lake}

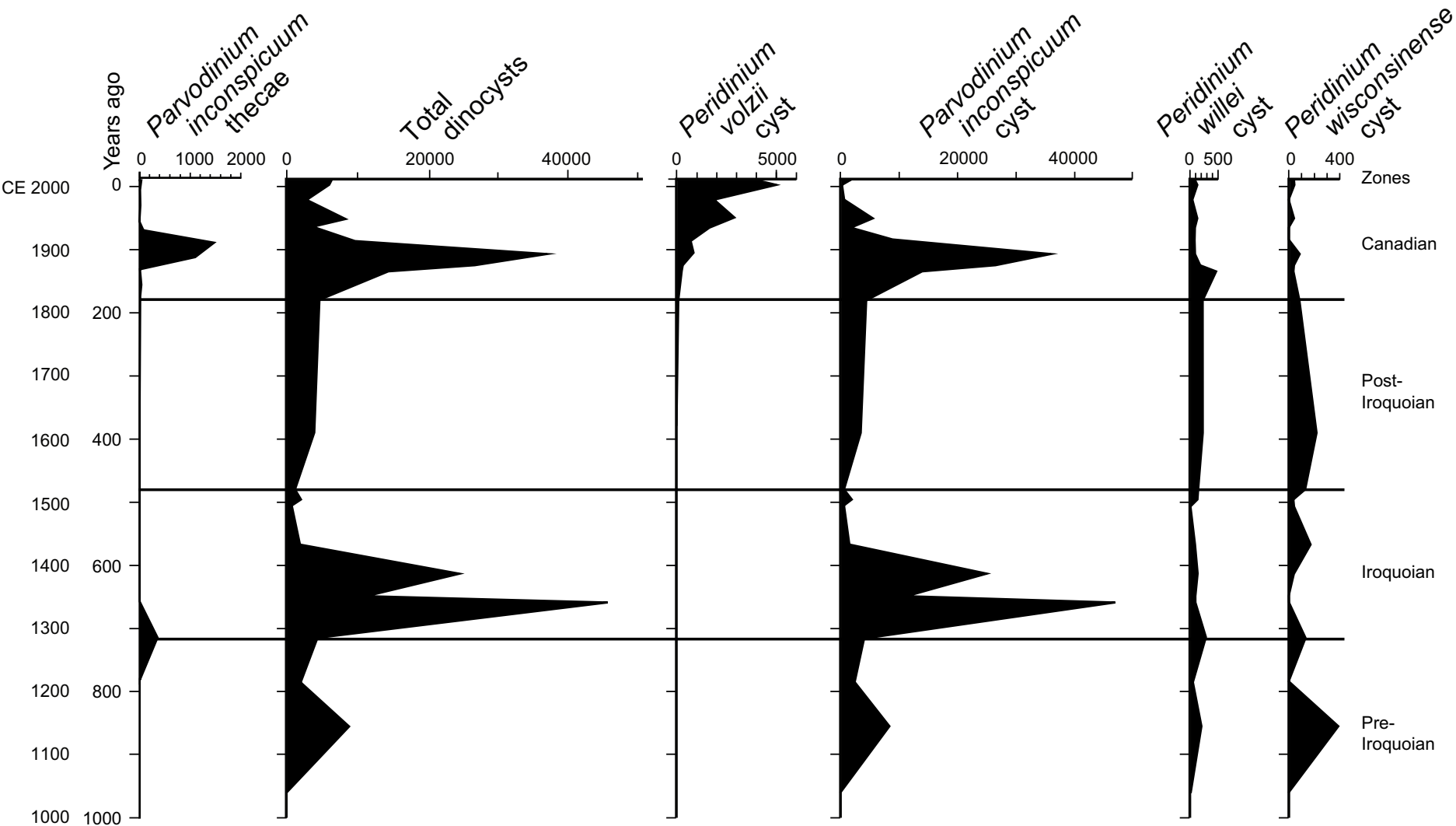

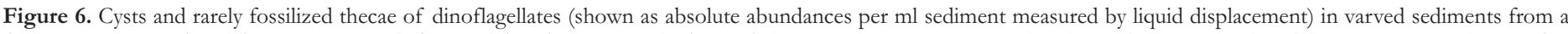

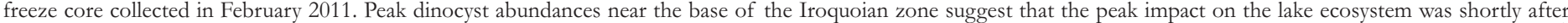

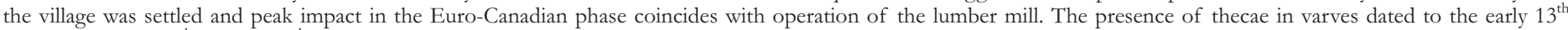

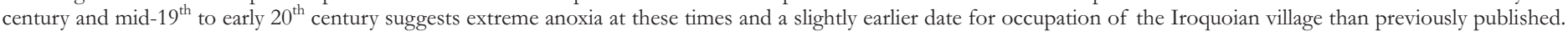




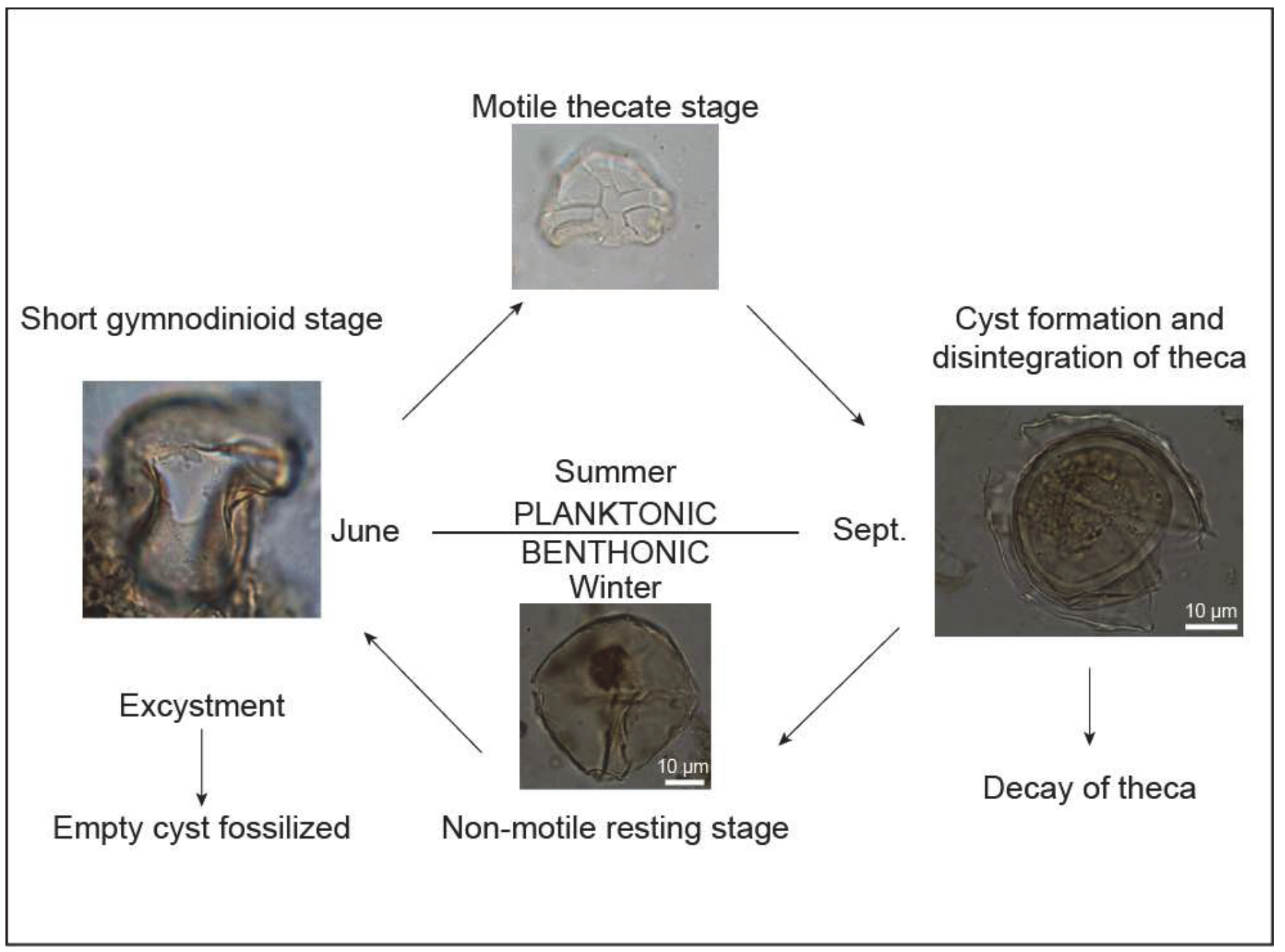

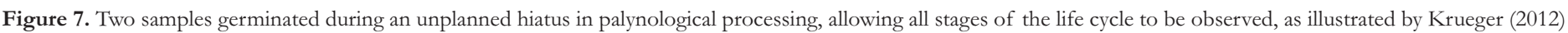

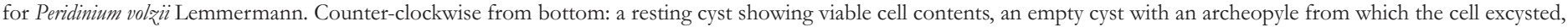
the epitheca of the motile stage made of cellulosic plates, and an encystment and sloughing of the theca to avoid adverse conditions.

species to eutrophic conditions (Koryak 1978; Moiseenko 2005), particularly when $\mathrm{pH}$ is above 6 (Perez et al. 1994), as it is in this dolomitic basin.

The oldest dinoflagellate to excyst was from varves deposited in Crawford Lake around AD 1820; just as the Crawford family began clearing land in the catchment to build their homestead according to McAndrews and BoykoDiakonow (1989). The cysts of P. inconspicuum that germinated are nearly twice as old as the oldest cysts of Pentapharsodinium dalei Indelicato et Loeblich that Ribeiro et al. (2011) were able to germinate from sediment cores retrieved from a low-oxygen sill fjord, and much older than previous reports of cyst germination following decades of dormancy (Keafer et al. 1992; McQuoid et al. 2002; Mizushima and Matsuoka 2004). Anoxic conditions in the deep basin of Crawford Lake appear to have promoted the long-term viability of the resting cysts that may have contributed to the survival of these cyst-forming genera during times of ecological catastrophe like the $\mathrm{K}-\mathrm{T}$ boundary event (Ribeiro et al. 2011).

The inadvertent excystment during processing also allowed small (approximately $30 \times 40 \mu \mathrm{m}$ ) slightly ovate non-motile dinosporin resting cysts previously recorded as Peridinium willei ('small') in sediments from Georgian Bay (McCarthy et al. 2011) to be assigned to Peridinium volzii Lemmermann (Krueger 2012). The restriction of cysts of P. volzii as well as the loricae of Keratella earlinae and Keratella quadrata to varves deposited since about 1880 CE (Figs. 2, 6) suggests that these organisms were incidentally introduced when the naturally fishless lake was stocked with fish (Turton, C., personal communication 2011; Krueger 2012), around the same time that a lumber mill was erected by the south end of the lake (Crawford Lake Conservation Area 2011).

\section{CULTURAL EUTROPHICATION, ENHANCED PRODUCTIVITY AND PRESERVATION}

An increase in absolute abundance of aquatic microfossils (biomass) and a transition from oligotrophic to eutrophic species assemblages is evident in the fossil record of phytoplankton (diatoms - Ekdahl et al. 2004, 2007, and dinoflagellates - Krueger 2012; McCarthy and Krueger 2013) as well as herbivores like rotifers (Turton and McAndrews 2006) that thrived in response to the increase in food supply during the 
two separate human settlement phases (Fig. 2). The exceptional preservation of cellulosic thecae and the unparalleled longevity of cell contents is attributed to especially pronounced bottom water anoxia resulting from cultural eutrophication-induced sediment oxygen demand (SOD) (Hargrave 1972; Walker and Snodgrass 1986), evident in the suppression of benthic diatoms (Fig. 2) (Ekdahl 2004, 2007) and benthic ostracodes that was only episodically interrupted (Chan, C.C.H., unpublished data). Peak anoxia appears to coincide with 1) initial settlement and land clearing beginning in 1822 $\mathrm{CE}$ and lumbering on the shores of Crawford Lake during the 1880s (Krueger 2012) recorded by thick accumulations of woody debris near the base of the Ambrosia rise near the north shore of the lake (McCarthy et al. 2011), and 2) during the earliest phase of Iroquoian settlement, when the village was established and trees were cut to clear land for the village and corn fields and to provide building material for the longhouses. McAndrews and Turton $(2007,2010)$ suggested that increased nutrient input from the dung of Canada geese (Branta canadensis) that grazed on the cultivated fields and then roosted at Crawford Lake was the main cause of eutrophication during Iroquoian settlement. The peak concentrations of cellulosic thecae (around 1500 thecae per $\mathrm{ml}$ ) in varves deposited coincident with the establishment of the lumber mill suggests that Euro-Canadian land clearing was the most intense contributor to $\mathrm{BOD} / \mathrm{SOD}$.

It is clear from the increase in algal (diatom and dinoflagellate) and herbivore (rotifer) biomass and from the changes in assemblages to favour eutrophic plankton and nekton (Figs. 2, 6 ) that the Iroquoian village had a strong and irreversible impact on the lacustrine ecosystem. Although there was resurgence in oligotrophic algae (e.g. Cyclotella bodanica var. lemanica and Peridinium wisconsinense) during the post-Iroquoian interval, the lake did not return to pre-disturbance conditions.

\section{CONCLUSIONS}

Preservation of rarely fossilized microscopic organisms in varved sediments from Crawford Lake, notably cellulosic thecae and cysts of dinoflagellates with viable cell contents deposited nearly 200 years ago, allowed reconciliation of the thanatocoenosis with the biocoenosis in this unusual group of organisms. Exceptional preservation of organisms rarely present in lacustrine sediment allows unparalleled insights into the response to perturbation of various trophic levels in a mid-latitude lacustrine ecosystem. The correspondence between the palynological record in the varves from Crawford Lake and the components of the ecosystem is closer than typically found in lacustrine sediment, allowing insights from the phycological and zoological literature into dinoflagellate cyst-theca relationships. Varve counting provides a precise chronology allowing correlation with archaeological and historic records, and the increase in nutrients that accompanied Iroquoian and later Euro-Canadian settlement of the uplands north of the small, deep lake promoted the bottom water anoxia that allowed exceptional preservation of dinoflagellate thecae and rotifer loricae. The existence of an interpretive centre managed by Conservation Halton in this Area of Natural and Scientific Interest (ANSI) on the edge of the Niagara Escarpment World Biosphere Reserve provides an opportunity to promote Konservat-Lagerstätten to the general public in a highly populat- ed region. In addition, the insights into the various trophic levels in this temperate lake as extant primary producers and consumers twice responded to cultural eutrophication can assist in linking the fields of limnology and paleolimnology allowing for improved management of important fresh water resources.

\section{ACKNOWLEDGEMENTS}

We are grateful to Conservation Halton for allowing access to Crawford Lake to obtain the freeze core and to Charlie Turton and Jock McAndrews for their assistance with collecting, subsampling and interpreting the core. Olena Volik provided a photograph of a cyst with an archeopyle for the life cycle figure, Dr. Martin Head provided taxonomic insights, and Mike Lozon assisted with drafting. Special thanks for all their help with editing to Dave Rudkin and Graham Young.

\section{REFERENCES}

Allison, P.A., and Briggs, D.E.G., 1993, Exceptional fossil record: distribution of soft-tissue preservation through the Phanerozoic: Geology, v. 21, p. 527-530, http://dx.doi.org/10.1130/0091-7613(1993)021<0527:EFRDOS>2.3.CO;2.

Batten, D.J., Gray, J., and Harland, R., 1999, Palaeoenvironmental significance of monospecific assemblage of dinoflagellate cysts from the Miocene Clarkia beds, Idaho, USA: Palaeogeography, Palaeoclimatology, Palaeoecology, v. 153, p. 161-177, http://dx.doi.org/10.1016/S0031-0182(99)00103-0.

Bell, M.A., Sadagursky, M.S., and Baumgartner, J.V., 1987, Utility of lacustrine deposits for the study of variation within fossil samples: PALAIOS, v. 2, p. 455 466, http://dx.doi.org/10.2307/3514617.

Boyko, M., 1973, European impacts on the vegetation around Crawford Lake in Southern Ontario: Unpublished MSc thesis, Department of Botany, University of Toronto, ON, 114 p.

Bradley, W.H., 1931, Origin and microfossils of the oil shale of the Green River Formation of Colorado and Utah: U.S. Geological Survey Professional Paper, 168 p. $1-58$.

Bravo, I., and Figueroa, R.I., 2014, Towards an ecological understanding of dinoflagellate cyst functions: Microorganisms, v. 2, p. 11-32, http://dx.doi.org/ 10.3390/microorganisms2010011.

Buchheim, H.P., and Surdham, R., 1981, Paleoenvironments and fossil fishes of the Laney Member, Green River Formation, Wyoming, in Gray, J., Boucot, A.J., and Berry, W.B.N., eds., Communities of the Past: Hutchinson Ross, New York, 425 p.

Byrne, R., and Finlayson, W.D., 1998, Iroquoian agriculture and forest clearance at Crawford Lake, Ontario, in Finlayson, W.D., ed., Iroquoian Peoples of the Land of Rocks and Water A.D. 1000-1650: a Study in Settlement Archaeology: London Museum Special Publication, 1, p. 94-107.

Byrne, R., and McAndrews, J.H., 1975, Pre-Columbian purslane (Portulaca oleracea L) in the New World: Nature, v. 253, p. 726-727, http://dx.doi.org/10.1038/ $253726 \mathrm{a} 0$.

Cabecinha, E., Cortes, R., Cabral, J.A., Ferreira, T., Lourenço, M., and Pardal, M.Â., 2009 , Multi-scale approach using phytoplankton as a first step towards the definition of the ecological status of reservoirs: Ecological Indicators, v. 9, p. 240 255, http://dx.doi.org/10.1016/j.ecolind.2008.04.006.

Carty, S., 2014, Freshwater Dinoflagellates of North America: Cornell University Press, Ithaca, NY, 272 p.

Chu, G., Sun, Q., Rioual, P., Boltovskoy, A., Liu, Q., Sun, P., Han, J., and Liu, J., 2008, Dinocyst microlaminations and freshwater 'red tides' recorded in Lake Xiaolongwan, northeastern China: Journal of Paleolimnology, v. 39, p. 319-333, http://dx.doi.org/10.1007/s10933-007-9106-1.

Dickman, M.D., 1979, A possible varving mechanism for meromictic lakes: Quaternary Research, v. 11, p. 113-124, http://dx.doi.org/10.1016/00335894(79)90072-3.

Drljepan, M., 2014, Algal and protozoan response to Holocene climate change and anthropogenic impact: a case study from Sluice Pond, MA: Unpublished MSc thesis, Brock University, St. Catharines, ON, 200 p.

Drljepan, M., McCarthy, F.M.G., and Hubeny, J.B., 2014, Natural and cultural eutrophication of Sluice Pond, Massachusetts, USA, recorded by algal and protozoan microfossils: The Holocene, v. 24, p. 1731-1742, http://dx.doi.org/ $10.1177 / 0959683614551227$

Ekdahl, E.J., Teranes, J.L., Guilderson, T.P., Turton, C.L., McAndrews, J.H., Wittkop, C.A., and Stoermer, E.F., 2004, Prehistorical record of cultural eutrophication from Crawford Lake, Canada: Geology, v. 32, p. 745-748, http://dx.doi.org/10.1130/G20496.1.

Ekdahl, E.J., Teranes, J.L., Wittkop, C.A., Stoermer, E.F., Reavie, E.D., and Smol, J.P., 2007, Diatom assemblage response to Iroquoian and Euro-Canadian eutrophication of Crawford Lake, Ontario, Canada: Journal of Paleolimnology, v. 37, p. 233-246, http://dx.doi.org/10.1007/s10933-006-9016-7.

Fensome, R.A., Taylor, F.J.R., Norris, G., Sarjeant, W.A.S., Wharton, D.I., and 
Williams, G.L.,1993, A Classification of Living and Fossil Dinoflagellates: Micropaleontology Special Publication 7: Sheridan Press, Hanover, PA.

Finlayson, W.D., editor, 1998, Iroquoian Peoples of the Land of Rocks and Water A.D. 1000-1650: A Study in Settlement Archaeology: London, Ontario: London Museum Archaeology Special Publication, 1, p. 1-425.

Finlayson, W.D., Byrne, A.R., and McAndrews, J.H., 1973, Iroquoian settlement and subsistence patterns near Crawford Lake, Ontario: Bulletin of the Canadian Archaeological Association, v. 5, p. 134-136.

Grande, L., 1980, The paleontology of the Green River Formation, with a review of the fish fauna: Geological Survey of Wyoming Bulletin, v. 63, p. 1-334.

Hargrave, B.T., 1972, Oxidation-reduction potentials, oxygen concentration, and oxygen uptake of profundal sediments in a eutrophic lake: Oikos, v. 23, p. $167-$ 177, http://dx.doi.org/10.2307/3543402.

Head, M.J., 1996, Modern dinoflagellate cysts and their biological affinities, in Jansonius, J., and McGregor, D.C., eds., Palynology: Principles and Applications: American Association of Stratigraphic Palynologists Foundation, v. 3, p. 1197 1248.

Hutchinson, G.E., editor, 1957, A Treatise on Limnology. Vol. I: Wiley, New York, NY, 1015 p.

Jha, N., Kumar, P., Aggarwal, N., Bhattacharyya, D.D., and Pande, A.C., 2011, The oldest bdelloid rotifer from Early Permian sediments of Chamba Valley: a new discovery: International Journal of Geology, Earth and Environmental Sciences, v. 1, p. 23-29.

Keafer, B.A., Buesseler, K.O., and Anderson, D.M., 1992, Burial of living dinoflagellate cysts in estuarine and nearshore sediments: Marine Micropaleontology, v. 20, p. 147-161, http://dx.doi.org/10.1016/0377-8398(92)90004-4.

Kidwell, S.M., and Flessa, K.W., 1996, The quality of the fossil record: Populations, species and communities: Annual Review of Earth and Planetary Sciences, v. 24, p. 443-464, http://dx.doi.org/10.1146/annurev.earth.24.1.433.

Köhler, J., and Clausing, A., 2000, Taxonomy and palaeoecology of dinoflagellate cysts from Upper Oligocene freshwater sediments of Lake Enspel, Westerwald area, Germany: Review of Palaeobotany and Palynology, v. 112, p. 39-49, http://dx.doi.org/10.1016/S0034-6667(00)00034-8.

Kokinos, J.P., Eglinton, T.I., Goñi, M.A., Boon, J.J., Martoglio, P.A., and Anderson, D.M., 1998, Characterisation of a highly resistant biomacromolecular material in the cell wall of a marine dinoflagellate resting cyst: Organic Geochemistry, v. 28, p. 265-288, http://dx.doi.org/10.1016/S0146-6380(97)00134-4.

Koryak, M., 1978, The occurrence of Peridinium inconspicuum Lemmermann (Dinophyceae) in minerally acid waters of the Upper Ohio River Basin: Proceedings of the Academy of Natural Sciences of Philadelphia, $130 \mathrm{p}$.

Krueger, A.M., 2012, Freshwater dinoflagellates as proxies of cultural eutrophication: a case study from Crawford Lake, Ontario: Unpublished MSc thesis, Department of Earth Sciences, Brock University, St. Catharines, ON, 96 p.

Masure, E., Dejax, J., and De Ploëg, G., 2013, Blowin' in the wind...100 Ma old multi-staged dinoflagellate with sexual fusion trapped in amber: Marine-freshwater transition: Palaeogeography, Palaeoclimatology, Palaeoecology, v. 388, p. 128-144, http://dx.doi.org/10.1016/j.palaeo.2013.08.008.

McAndrews, J.H., and Boyko-Diakonow, M., 1989, Pollen analysis of varved sediments at Crawford Lake, Ontario: evidence of Indian and European farming, in Fulton R.J., ed., Quaternary Geology of Canada and Greenland: Geological Society of America, Boulder, Colorado, USA, 528 p.

McAndrews, J.H., and Turton, C.L., 2007, Canada geese dispersed cultigen pollen grains from prehistoric Iroquoian fields to Crawford Lake, Ontario, Canada: Palynology, v. 31, p. 9-18, http://dx.doi.org/10.2113/gspalynol.31.1.9.

McAndrews, J.H., and Turton, C.L., 2010, Fungal spores record Iroquoian and Canadian agriculture in 2nd millennium A.D. sediment of Crawford Lake, Ontario, Canada: Vegetation History and Archaeobotany, v. 19, p. 495-501, http://dx.doi.org/10.1007/s00334-010-0237-3.

McCarthy, F.M.G., and Krueger, A.M., 2013, Freshwater dinoflagellates in palaeolimnological studies: Peridinium cysts as proxies of cultural eutrophication in the SE Great Lakes region of Ontario, Canada, in Lewis, J.M., Marret, F., and Bradley, L., eds., Biological and Geological Perspectives of Dinoflagellates: The Micropalaeontological Society, Special Publications, Geological Society, London, p. 133-139.

McCarthy, F.M.G., Mertens, K.N., Ellegaard, M., Sherman, K., Pospelova, V., Ribeiro, S., Blasco, S., and Vercauteren, D., 2011, Resting cysts of freshwater dinoflagellates in southeastern Georgian Bay (Lake Huron) as proxies of cultural eutrophication: Review of Palaeobotany and Palynology, v. 166, p. 46-62, http://dx.doi.org/10.1016/j.revpalbo.2011.04.008.

McQuoid, M.R., Godhe, A., and Nordberg, K., 2002, Viability of phytoplankton resting stages in the sediments of a coastal Swedish fjord: European Journal of Phycology, v. 37, p. 191-201, http://dx.doi.org/10.1017/S0967026202003670.

Mertens, K.N, Rengefors, K., Moestrup, Ø., and Ellegaard, M., 2012, A review of recent freshwater dinoflagellate cysts: taxonomy, phylogeny, ecology and palaeocology: Phycologia, v. 51, p. 612-619, http://dx.doi.org/10.2216/1189.1
Mizushima, K., and Matsuoka, K., 2004, Vertical distribution and germination ability of Alexandrium spp. cysts (Dinophyceae) in the sediments collected from Kure Bay of the Seto Inland Sea, Japan: Phycological Research, v. 52, p. 408-413, http://dx.doi.org/10.1111/j.1440-1835.2004.tb00349.x.

Moiseenko, T.I., 2005, Effects of acidification on aquatic ecosystems: Russian Journal of Ecology, v. 36, p. 93-102, http://dx.doi.org/10.1007/s11184-005-0017-

Niagara Escarpment Commission, 2005, Niagara Escarpment Plan: Government of Ontario Ministry of Natural Resources, 148 p. Available at: http://www.escarpment.org/landplanning/plan/index.php.

Oeggl, K., Kofler, W., Schmidl, A., Dickson, J.H., Egarter-Vigl, E., and Gaber, O., 2007, The reconstruction of the last itinerary of "Ötzi", the Neolithic Iceman, by pollen analyses from sequentially sampled gut extracts: Quaternary Science Reviews, v. 26, p. 853-861, http://dx.doi.org/10.1016/j.quascirev.2006.12.007.

Painter, T.J., 1991, Lindow Man, Tollund Man and other peat-bog bodies: The preservative and antimicrobial action of sphagnan, a reactive glycuronoglycan with tanning and sequestering properties: Carbohydrate Polymers, v. 15, p. 123-142, http://dx.doi.org/10.1016/0144-8617(91)90028-B

Perez, E.A.A., DeCosta, J., and Havens, K.E., 1994, The effects of nutrient addition and $\mathrm{pH}$ manipulation in bag experiments on the phytoplankton of a small acidic lake in West Virginia, USA: Hydrobiologia, v. 291, p. 93-103, http://dx.doi.org/10.1007/BF00044438.

Pfiester, L.A., Timpano, P., Skvarla, J.J., and Holt, J.R., 1984, Sexual reproduction and meiosis in Peridinium inconspicuum Lemmermann (Dinophyceae): American Journal of Botany, v. 71, p. 1121-1127, http://dx.doi.org/10.2307/2443388.

Popovský, J., 1983, Problems in the determination of freshwater dinoflagellates (Dinophyceae): Schweizerische Zeitschrift für Hydrologie, v. 45, p. 365-372, http://dx.doi.org/10.1007/bf02538126.

Popovský, J., and Pfiester, L.A., 1990, Dinophyceae (Dinoflagellida), in Ettl, H., Gerloff, J., Heyning, H., and Mollenhauer, D., eds., Süßwasserflora von Mitteleuropa 6: Spektrum, Jena, Germany.

Poschmann, M., Schindler, T., and Dieter, U., 2010, Fossil-Lagerstätte Enspel - a short review of current knowledge, the fossil association, and a bibliography: Palaeobiodiversity and Palaeoenvironments, v. 90, p. 3-20, http://dx.doi.org/ 10.1007/s12549-009-0017-1

Ribeiro, S., Berge, T., Lundholm, N., Andersen, T.J., Abrantes, F., and Ellegaard, M., 2011, Phytoplankton growth after a century of dormancy illuminates past resilience to catastrophic darkness: Nature Communications, 2:311, http://dx.doi.org/10.1038/ncomms1314.

Schindel, D.E., 1980, Microstratigraphic sampling and the limits of paleontologic resolution: Paleobiology, v. 6, p. 408-426.

Smiley, C.J., and Rember, W.C., 1981, Paleoecology of the Miocene Clarkia Lake (northern Idaho) and its environs, in Gray, J., Boucot, A.J., and Berry, W.B.N., eds., Communities of the Past: Hutchinson Ross, Stroudsburg, PA, 551 p.

Smiley, C.J., and Rember, W.C., 1985, Physical setting of the Miocene Clarkia fossil beds, northern Idaho, in Smiley, C.J., ed., Late Cenozoic History of the Pacific Northwest (Interdisciplinary Studies on the Clarkia Fossil Beds of Northern Idaho): Pacific Division, American Association for the Advancement of Science, San Francisco, p. 11-31.

Smol, J.P., 2010, The power of the past: using sediments to track the effects of multiple stressors on lake ecosystems: Freshwater Biology, v. 55, p. 43-59, http://dx.doi.org/10.1111/j.1365-2427.2009.02373.x.

Swadling, K.M., Dartnall, H.J.G., Gibson, J.A.E., Saulnier-Talbot, É., and Vincent, W.F., 2001, Fossil rotifers and the early colonization of an Antarctic lake: Quaternary Research, v. 55, p. 380-384, http://dx.doi.org/10.1006/qres.2001.2222.

Tardio, M., Sangiorgi, F., Brinkhuis, H., Filippi, M.L., Cantonati, M., and Lotter, A.F., 2006, Peridinioid dinoflagellate cysts in a Holocene high-mountain lake deposits in Italy: Journal of Paleolimnology, v. 36, p. 315-318, http://dx.doi.org/10.1007/s10933-006-9001-1.

Traverse, A., 1955, Pollen analysis of Brandon lignite of Vermont: U.S. Department of the Interior, Bureau of Mines, Internal Report, 5151, 107 p., 13 pl.

Turton, C.L., and McAndrews, J.H., 2006, Rotifer loricas in second millennium sediment of Crawford Lake, Ontario, Canada: Review of Palaeobotany and Palynology, v. 141, p. 1-6, http://dx.doi.org/10.1016/j.revpalbo.2006.03.017.

van Geel, B., 2001, Non-pollen palynomorphs, in Smol, J.P., Birks, H.J.B., and Last, W.M., eds., Tracking Change Using Lake Sediments. Volume 3: Terrestrial, Algal, and Siliceous Indicators: Kluwer, Dordrecht, p. 99-119.

Versteegh, G.J.M., Blokker, P., Bogus, K.A., Harding, I.C., Lewis, J., Oltmanns, S., Rochon, A., and Zonneveld, K.A.F., 2012, Infrared spectroscopy, flash pyrolysis, thermally assisted hydrolysis and methylation (THM) in the presence of tetramethylammonium hydroxide (TMAH) of cultured and sediment derived Lingulodinium polyedrum (Dinoflagellata) cyst walls: Organic Geochemistry, v. 43 , p. $92-102$

Waggoner, B.M., and Poinar, G.O., Jr., 1993, Fossil habrotrochid rotifers in Dominican amber: Experientia, v. 49, p. 354-357.

Walker, R.R., and Snodgrass, J.R., 1986, Model for sediment oxygen demand in lakes: 
Journal of Environmental Engineering, v. 112, p. 25-43.

Wall, D., and Dale, B., 1968, Modern dinoflagellate cysts and evolution of Peridiniales: Micropaleontology, v. 14, p. 265-304.

Yu, Z., McAndrews, J.H., and Eicher, U., 1997, Middle Holocene dry climate caused by change in atmospheric circulation patterns: Evidence from lake levels and stable isotopes: Geology, v. 25, p. 251-254, http://dx.doi.org/10.1130/00917613(1997)025<0251:MHDCCB>2.3.CO;2.

Received May 2014

Accepted as revised December 2015

First published on the web January 2016 